\title{
Food Security in India: Performance and Concerns
}

\author{
Prof. Kalpana Singh \\ Amity School of Economics/Amity University, Noida, UP, India
}

\begin{abstract}
One of the prime concerns of India's policies has been the food and nutritional security to its population. The three important components of food security are: availability, access, and absorption (nutrition). These three are interrelated. The major aim of this paper is to examine the performance in food security in India in respect of these three components. In respect of availability, The average annual growth rates in Yields of Food grain Production and in Area under cultivation for Food grain Production have been computed for five time periods; pre green revolution 1950-51 to 66-67), early green revolution (1967-68 to 1979-80), mature green revolution (1980-81 to 1989-90), early economic reforms (1990-91 to 1999-00), and economic reforms (2000-01 to 2011-12). The food grains production has deteriorated when India entered in the era of globalization. The free market play has adversely affected the production of food grains and the rate of growth of food grains production declined after the introduction of New Economic Policy (NEP) in India. So far as the accessibility aspect of food security is concerned, long term trend in consumption pattern at household level shows that per capita direct consumption of food grains has been declining. Further India's performance in food security on nutritional outcomes has not been very satisfactory. The Global Food Security Index 2012 released in New Delhi in September, 2012, placed India in a "moderate" category. It ranked India 66th among 105 nations and cited affordability rather than availability as a key food security threat for Indians. India scored highest in food availability (51.3) but lowest (38.4) in terms of food access. It also points to its poor ability to move food efficiently because of infrastructure problems. Similarly, in food security index 2013, India slipped to $70^{\text {th }}$ position. We live in paradoxical times, and it is not the shortage of food but the lack of a proper food distribution network that is to blame.
\end{abstract}

Keywords: Absorption, Access, Availability, Food Management, Food Security

\section{Introduction}

One of the prime concerns of India's policies has been the food and nutritional security to its population. The demand for food grains increases and gets diversified with increase in population, income and urbanization. A large section of our population continues to suffer from malnutrition and inadequacy of food grains in spite of the fact that food grain production from 1950-51 (50.82 mt) to 2008-09 (233.88 mt), has increased four times [1]. Ensuring food security is an important issue for a country like India where more than one-third of the population is estimated to be absolutely poor and almost fifty percent of all children malnourished in one way or another, [2].

\subsection{What is Food Security?}

Reflecting the varying concerns of the academics, the practitioners etc., various definitions of food security have been used since 1970s. As Frankenberger and Maxwell (1992) document that for the roots of concern with food security, we can trace back to the World Food Crisis in $1972-74$; and, beyond that to the Universal Declaration of Human Rights (1948), which recognized right to food as a core element of an adequate standard of living [3]. Food security became a key concept only in the 1970s and the 1980s and around it theoretical frameworks and analysis of undernourishment began to be developed. In the 1970s, many of the definitions of food security focused on the importance of the physical availability of foodstocks. In the specific context of India, the 'Green Revolution' (GR) of the late 1960s and early 1970s which substantially increased food production by raising productivity levels, made it appear that the availability of food at the national level was not a big problem. In India which was previously a food-deficit country, surplus food stocks were built up.But this did not imply the absence of under nutrition or absence of food insecurity for a large section of the population. With apparent achievement of 'self-sufficiency' in food grain, in the 1980s the focus of analysis shifted to the question of economic access to food at the household level.

According to Food and Agricultural Organisation, food security means ensuring that all people at all times have both physical and economic access to the basic food they need [3]. As defined by the World Bank (WB) in 1986, food security is access to enough food by all people at all times for an active and healthy life [3].Thus, the physical availability of food stocks and economic and physical access to food stocks are not the only problems that are included in food security concerns, but biological utilisation of food consumed is also important. That is, a more inclusive conception of food security, includes environmental conditions such as 
availability or otherwise of safe drinking water and sanitation as well as nutrition practices and knowledge that can help or hinder the absorption of food into the body.

According to the World Food Summit of 1996, food security is said to exist when, in order to maintain a healthy and active life, all people at all times have access to sufficient, safe, nutritious food [4].

According to Food and Agriculture Organization (FAO), for the food security to exist, it is necessary that to meet their dietary needs and food preferences, all people, at all times, have physical and economic access to sufficient, safe, and nutritious food for an active and healthy life. Thus, three components of food security are: availability, access, and absorption (nutrition). These three are interrelated. It has been shown by many studies that even for increase in productivity of workers, improvement in nutrition is important. Thus, there is intrinsic (for its own sake) as well as instrumental (for increasing productivity) value of food security [2].

\subsection{Objectives of the Study}

The major aim of this paper is to examine the performance in food security in India along with some concerns relating to food security in respect of the following:

(i) Availability of Food (total as well as per capita) including Food management and Buffer stock aspects

(ii) Access to Food

(iii) Absorption of Food (Nutritional aspect)

The second part of the paper focuses on examining the food availability status in India. The third part of the paper examines the accessibility aspect of food security in India both in terms of consumption and nutrition indicators. Part fourth of the Paper summarises the major findings of the study.

\subsection{Methodology}

The present study is based on secondary data and information collected from a variety of sources. To examine the availability aspect of food security, average annual growth rates of production, area under cultivation and yield of food grain production for crop groups (cereals, Pulses and Food Grains) during the period 1950-51 to 2011-12 have been computed for five time periods; pre green revolution 1950-51 to 66-67), early green revolution (1967-68 to 1979-80), mature green revolution (1980-81 to 1989-90), early economic reforms (1990-91 to 1999-00), and economic reforms (2000-01 to 2011-12).Further, using figures of decadal average, trends in Per capita net availability of food grains is analysed. To examine Accessibility and Absorption aspects of food security, figures for per capita direct consumption of cereals and pulses and Per capita Average Daily Intake of Proteins and Calories in India have been used and analysed.

\section{Availability Of Food}

In the post-independence period, one of the country's major achievements is attaining self-sufficiency in food grains at the national level. For about two decades after independence, India remained a food deficit country but later on it became largely self-sufficient in food grain production at the macro level.

\subsection{Total Food Grain Production}

As shown in Table A1, Food Grain production in the country, which was about 50 million tonnes in 1950-51, increased to around 234.47million tonnes in 2008-09. Thereafter it declined in 2009-10 to 218.11 and then again increased to 244.78 in 2010-11.

The average annual growth rates of production, area under cultivation and yield of food grain production for crop groups (cereals, Pulses and Food Grains) during the period 1950-51 to 2011-12 have been shown in Table-1, Table 2 and Table 3 respectively. The same have also been presented through Fig.1, Fig.2 and Fig.3. respectively.

TABLE-1 Average Annual Growth Rate in Food Grain Production (1950-51 to 2011-12)

\begin{tabular}{|l|c|c|c|c|c|}
\hline \multirow{2}{*}{ Crop } & \multicolumn{5}{|c|}{ Production } \\
\cline { 2 - 6 } & $1950-51$ to $66-67$ & $\begin{array}{c}1967-68 \text { to } 1979- \\
80\end{array}$ & $\begin{array}{c}1980-81 \text { to } 1989- \\
90\end{array}$ & $\begin{array}{c}1990-91 \text { to } 1999- \\
00\end{array}$ & $\begin{array}{c}2000-01 \text { to 2011- } \\
12\end{array}$ \\
\hline Cereals & & 3.97 & 4.98 & 2.29 & 2.18 \\
\hline Pulses & 3.20 & 1.80 & 4.90 & 0.94 & 3.22 \\
\hline Total Food Grain & 1.03 & 3.93 & 4.96 & 2.18 & 2.22 \\
\hline
\end{tabular}

Source: Calculated by author from Table A1 
TABLE-2 Average Annual Growth Rate in Area under Cultivation for Food Grain Production (1950-51 TO 2011-12)

\begin{tabular}{|l|l|l|l|l|l|}
\hline \multirow{2}{*}{ Crop } & \multicolumn{5}{|c|}{ Area } \\
\cline { 2 - 6 } & $\begin{array}{l}1950-51 \text { to } 1966- \\
67\end{array}$ & $\begin{array}{l}1967-68 \text { to } \\
1979-80\end{array}$ & $\begin{array}{l}1980-81 \\
\text { to } 1989-90\end{array}$ & $\begin{array}{l}1990-91 \text { to } 1999- \\
00\end{array}$ & $\begin{array}{l}2000-01 \text { to } 2011- \\
12\end{array}$ \\
\hline Cereals & 1.12 & 0.81 & 0.10 & -0.12 & -0.06 \\
\hline Pulses & 1.01 & 0.23 & 0.65 & -0.91 & 2.04 \\
\hline Total Food Grain & 1.09 & 0.70 & 0.19 & -0.28 & 0.31 \\
\hline
\end{tabular}

Source: Calculated by author from Table A2

TABLE-3 Average Annual Growth Rate in Yields of Food Grain Production (1950-51 TO 2011-12)

\begin{tabular}{|l|l|l|l|l|l|}
\hline \multirow{2}{*}{ Crop } & \multicolumn{4}{|c|}{ Yield } \\
\cline { 2 - 6 } & $\begin{array}{l}1950-51 \text { to } 1966- \\
67\end{array}$ & $\begin{array}{l}1967-68 \text { to } 1979- \\
80\end{array}$ & $\begin{array}{l}1980-81 \text { to } 1989- \\
90\end{array}$ & $\begin{array}{l}1990-91 \text { to } 1999- \\
00\end{array}$ & $\begin{array}{l}2000-01 \text { to 2011- } \\
12\end{array}$ \\
\hline Cereals & 1.94 & 2.92 & 4.74 & 2.38 & 2.04 \\
\hline Pulses & -0.17 & 1.24 & 4.02 & 1.82 & 0.60 \\
\hline Total Food Grain & 1.61 & 2.78 & 2.62 & 2.43 & 1.52 \\
\hline
\end{tabular}

Source Calculated by author from Table A3

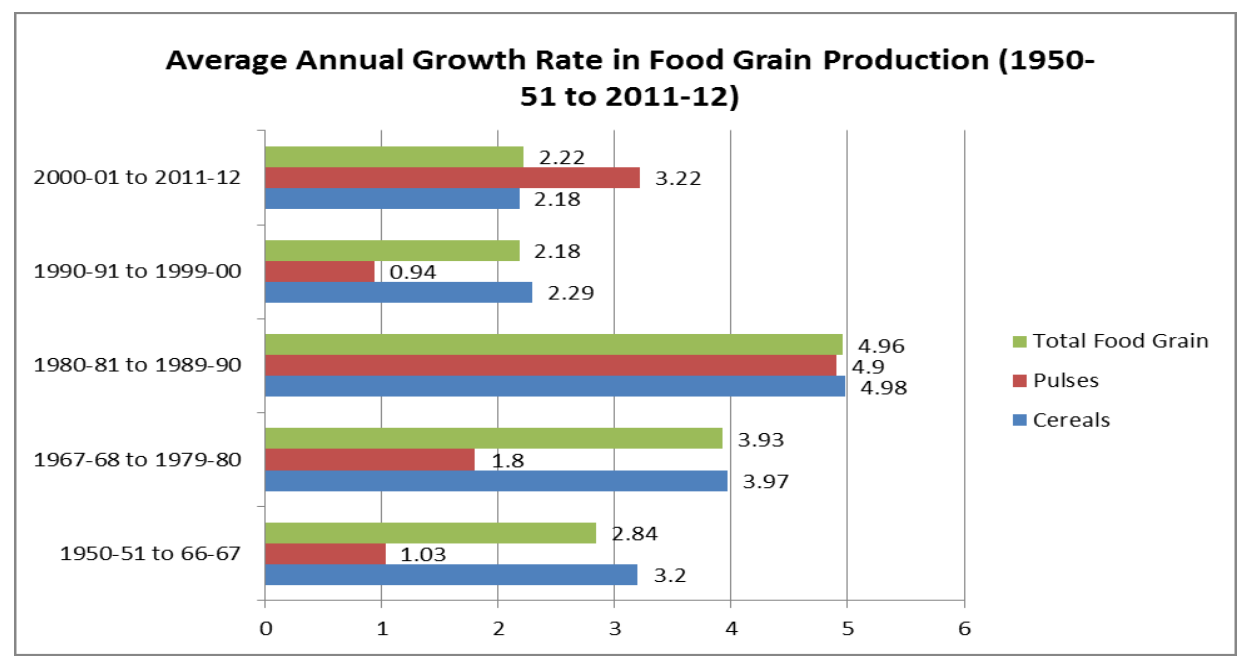

Source: Author's Compilation

Figure 1

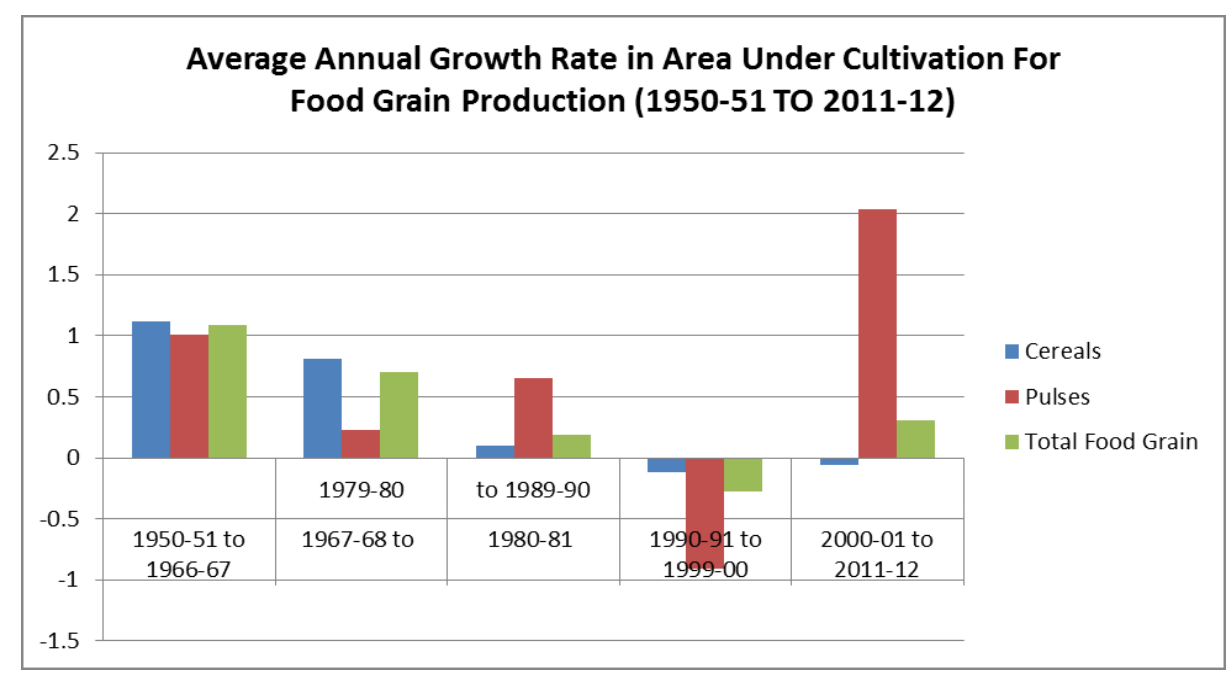

Source: Author's Compilation

Figure 2 


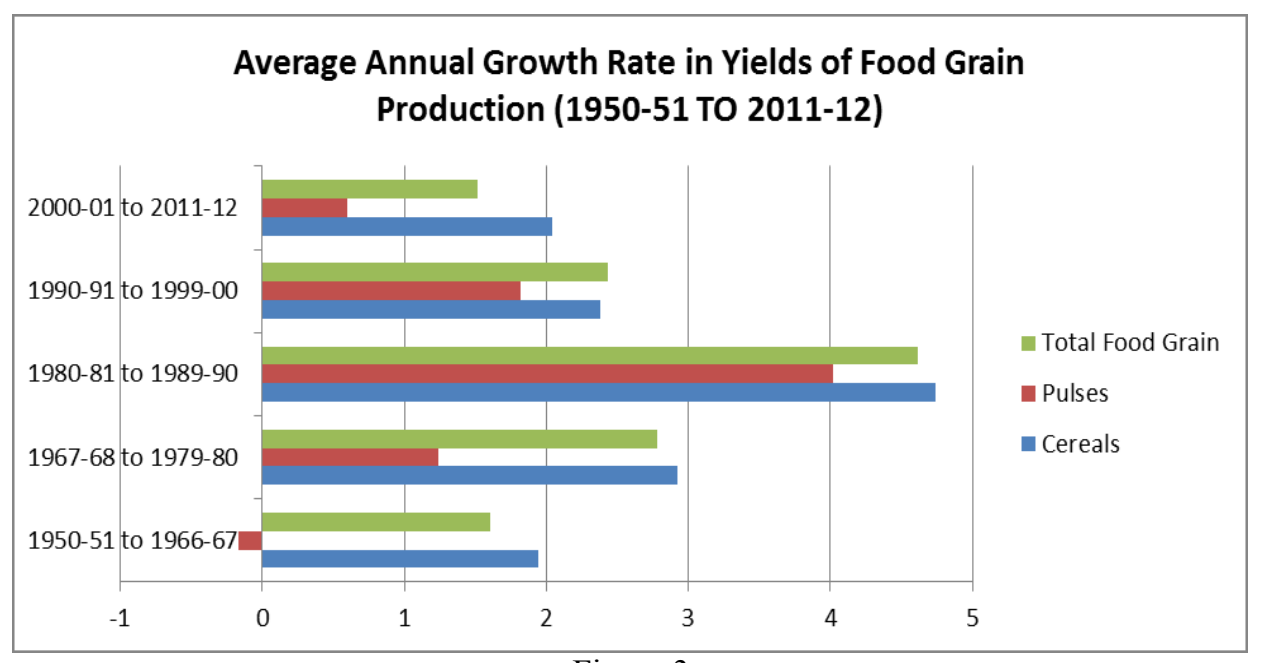

Figure 3

Source: Author's Compilation

The average annual growth rates have been computed for five time periods; pre green revolution 195051 to 66-67), early green revolution (1967-68 to 1979-80), mature green revolution (1980-81 to 1989-90), early economic reforms (1990-91 to 1999-00), and economic reforms (2000-01 to 2011-12) .

As evident from the Table 1, cereals, pulses and total food grain production registered average annual growth of 3.20, 1.03 and 2.84 per cent during the pre green revolution period (1950-51 to 66-67). In the early green revolution (1967-68 to 1979-80) and mature green revolution (1980-81 to 1989-90) periods, cereal, pulses and total food grain production registered higher and higher growth rates mainly because of high growth in yield. In early economic reforms (1990-91 to 1999-00) period all three had lower growth rates of production with negative growth in area. In the period 2000-01 to2011-12, the cereals and total food grain production registered average growth rates of 2.18 and 2.22 percent respectively (less than the rates even in pre green revolution period). The growth in area under cultivation for cereal production was again negative with very slight increase in area in case of total food grain production. The highest growth is registered in the production of pulses (3.22 percent) in the period 2000-01 to2011-12 with 2.04 percent growth in area under cultivation for pulses production.

\subsection{Reasons for Decline in Food Production Growth}

The decline in the growth of food production can be understood by the performance of the overall agriculture sector and the factors that are responsible for the slowdown. Concern over deceleration in Indian agriculture growth and the resultant threat to food security has also been explained by the Planning commission. Availability and access to food depends on the performance of agriculture as more than 55 per cent people in the country are dependent on this sector [2]. From the Fifth Plan period to theNinth Plan period agricultural growth in India was high - highest being in the Sixth Plan period, at around 5.7 per cent.

But if we consider longer periods, we find that growth of agriculture was 3.5 per cent between 1981-82 and 1996-97 which decelerated to around 2 per cent between 1997-98 and 2004-05, although in recent years, there have been signs of improvement [5]. In its 'Agriculture Strategy for Eleventh Plan' Planning Commission stated that a particular area of concern was food grains. Its production during $10^{\text {th }}$ plan was less than during $9^{\text {th }}$ plan. Per capita annual production of cereals has declined to only $174 \mathrm{~kg}$ in 2004/2007 while in 1991/1995 it was $192 \mathrm{~kg}$. In case of pulses, it declined from $15 \mathrm{~kg}$ to $12 \mathrm{~kg}$. This means that per capita food grains production is now at 1970s levels. Although, to some extent it is offset by increase in per capita availability of other food products, this raises valid concerns on food security. The report further stated that we must ensure growth in food grain production of at least 2 percent per annum in the $11^{\text {th }}$ Plan [6]. An immediate priority is to meet the food security concern stemming from stagnation of food grains, which still contribute about $65 \%$ of total calorie consumption in the country. The farm sector has grown at an average rate of around 3.2 per cent during the first four years of the Eleventh Plan still; we need faster farm sector growth to benefit poor farmers, many of whom are women. One of the reasons for increase in food prices over the last two years has been the below target growth in this sector [7].

Agriculture is facing both short run and long run problems. Growth rate in yield is onthe decline. Farming is fast becoming a non-viable activity. Further scope for increase in net sown area is limited. Depletion of soil fertility, erosion, and water logging has increased leading to land degradation. Surface irrigation expansion rate and the level of the ground water table have declined. Exposure of domestic agriculture to 
international competition has resulted in a high order of volatility in prices. Disparities in productivity have increased across regions and crops, and between rainfed and irrigated areas [2]. The Possible reasons for deceleration in agriculture since the mid-1990s were also identified by the Steering Committee report on agriculture for the Eleventh Plan [8].According to the report, public and private investment in agriculture and rural infrastructure including irrigation, technological change, diversification of agriculture, and fertilizers are the major sources of agricultural growth. It seems that progress on all these fronts has slowed down since the mid-1990s. Expansion has taken place only in the case of agricultural credit.

\subsection{Per Capita Availability of Food Grains}

Figure for net availability of food grains is obtained by subtracting the figures for requirement for seeds, farm animal feed, and waste from gross production and adding net imports, apart from adjustments for changes in government stocks. Per capita net availability of food grains in India increased during 1951 to 1991 and declined post 1991 (Table 4). At the present demographic growth rate, per capitaavailability of cereals may not remain comfortable especially of pulses and other cereals which have declined after 1991.

Per capita net availability of food grains increased by about 12 per cent over the last 58 years, between 1951 and 2009 (Table 4 \& Fig.4). However, net availability declined if we compare 1961 (469 grams per day) with 2009 (444 grams). In other words, significant increase in food grains has not been able to keep pace with the increase in population.

TABLE 4: Trends in Per Capita Availability of Food Grain in India (Decadal Average) (Gms/Person/Day)

\begin{tabular}{|c|c|c|c|}
\hline Year & Total cereals & pulses & Total Food grains \\
\hline 1951 & 334 & 61 & 395 \\
\hline 1961 & 400 & 69 & 469 \\
\hline 1971 & 418 & 51 & 469 \\
\hline 1981 & 417 & 38 & 455 \\
\hline 1991 & 469 & 42 & 510 \\
\hline 2001 & 386 & 30 & 416 \\
\hline 2007 & 407 & 35 & 443 \\
\hline 2008 & 395 & 42 & 436 \\
\hline 2009 & 407 & 37 & 444 \\
\hline 2010 & 401.7 & 35.4 & 437.1 \\
\hline 2011 & 410.7 & 43.0 & 453.7 \\
\hline $2012(p)$ & 408.2 & 41.6 & 449.8 \\
\hline
\end{tabular}

Source:

1. Agricultural Statistics at a Glance, 2011, DAC, Min of Agriculture, GOI for 1951-2009 [9].

2. Socio-Economic Indicators, Central Bureau of Health Intelligence - India, for 2010 [10].

3. Pocket Book on Agricultural Statistics, 2013, DAC, Min of Agriculture, GOI, for 2011 \& 2012[11].

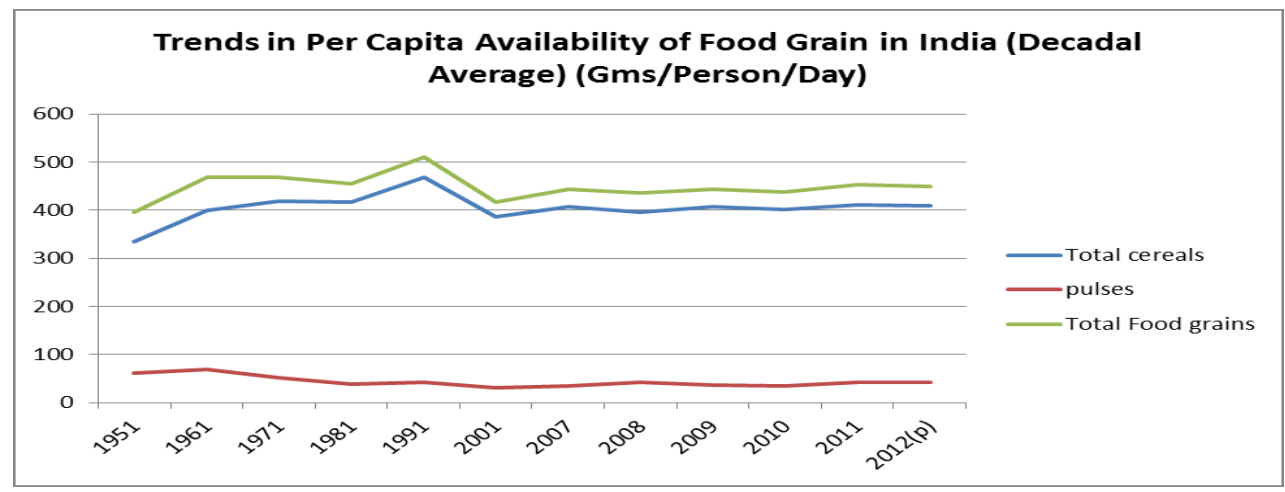

Figure 4

Source: Author's Compilation

In the year 2009, per capita availability of food grains was only 444 grams -- much lower than 510 grams in 1991. Per capita availability of food grains further declined to 437.1 grams per day in 2010 but rose to 453.7 grams per day in 2011 but still lower than the level attained about three decades ago i.e. in 1981.

During the period 1951 to 2010 , there has been a significant decline in per capita availability of pulses from 61 to 35.4 grams per day (i.e. a fall of 42 percent). 


\subsection{Food Management}

Food management is mainly aimed at procurement of food grains from farmers at remunerative prices, distribution of food grains to consumers at affordable prices, particularly the vulnerable sections of society and maintenance of food buffers for food security and price stability. In this respect, the instruments used are minimum support price (MSP) and Central issue price (CIP). The Food Corporation of India (FCI) is the nodal agency which undertakes procurement, distribution, and storage of food grains. Wheat and rice are purchased from the farmers in states where there is surplus production. A pre determined price known as Minimum Support Price (MSP) is paid to farmers for their crops. Procurement at MSP is open-ended, while distribution is governed by the scale of allocation and its off take by the beneficiaries. The off take of food grains is primarily under the targeted public distribution system (TPDS) and other welfare schemes of the Government of India.Under TPDS special cards are issued to BPL families to sell them food grains at specially subsidized prices with effect from June 1997. During the period 2004-05 to 2009-10, there has been significant increase in MSP as compared to the period 2000-01 to 2004-05 [2]. MSP for paddy (common variety) for example increased by 69.6 percent during 2004-05 to 2009-10 as compared to a 9.8 per cent rise during 2000-01 to 200405. Similarly, for wheat, MSP increased by 71 percent in the second half of this decade as compared to 8.6 per cent in the first half. For the years 2008-09 and 2009-10, there is a clear departure in MSPs from earlier years, in order to achieve the broad objectives of building buffer stocks of food grains to meet the situation of scarcity arising out of crop failures and to encourage farmers to grow more for food security concerns. They had similar objectives earlier as well, but, because of the slowdown in food grain yields and lower procurement prices, there was a concern in recent years particularly in 2006 07.During this year, India had to import 5 million tonnes of wheat. There was a significant increase in procurement of rice and wheat in the year 2008-09(56.8 million tonnes) compared to that in 2007-08 (39.8 million tonnes) as shown in Table 5 and Fig.5.The year 2011-12 also witnessed significant increase in total procurement of wheat and rice.

TABLE 5: Procurement of Rice and Wheat (in million tonnes)

\begin{tabular}{|c|c|c|c|}
\hline Year & Wheat & Rice & total \\
\hline $2003-04$ & 15.8 & 22.8 & 38.6 \\
\hline $2004-05$ & 16.8 & 24.6 & 41.4 \\
\hline $2005-06$ & 14.8 & 27.7 & 42.5 \\
\hline $2006-07$ & 9.2 & 25.1 & 34.3 \\
\hline $2007-08$ & 11.1 & 28.7 & 39.8 \\
\hline $2008-09$ & 22.7 & 34.1 & 56.8 \\
\hline $2009-10$ & 25.4 & 32.0 & 57.4 \\
\hline $2010-11$ & 22.5 & 34.2 & 56.7 \\
\hline $2011-12$ & 28.3 & 35.0 & 63.3 \\
\hline
\end{tabular}

Source: Economic Survey, GoI, Various Issues [12]

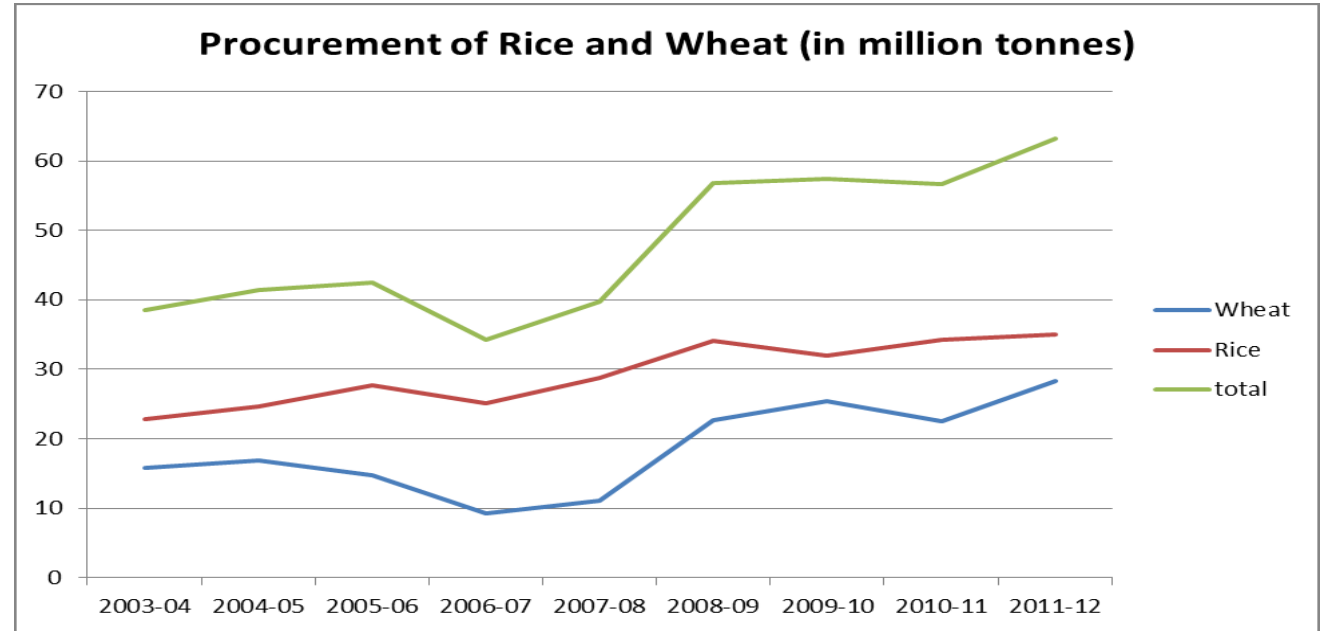

Figure 5

Source: Author's Compilation

\subsection{Buffer Stock}

To provide food security to the country, building up a buffer-stock of food grains -- normally rice and wheat assumes importance. Buffer-stocking is favoured on the ground that when, either due to weather conditions or due to man-made factors, there is large variation in food grain output, ensuring food security for 
the large mass of people becomes essential on the part of the state. This may be done by building adequate buffer stocks from the surpluses in years of good production and/or by making arrangements for the import of the requisite amounts of food grains in times of need. Regarding the optimal size of the buffer-stock, various committees have made their suggestions. In determining the minimum norm of food grains stocks required in a particular quarter of the year, the seasonality of production and procurement is a decisive factor. In addition to buffer norms, Government has prescribed 30 lakh tonnes of Wheat as Strategic Reserve w.e.f. 1.7.2008 and 20 lakh tonnes of Rice w.e.f. 1.1.2009[13].

For the years between 2002 and 2011, the actual level of and the norm for buffer stocks as on $1^{\text {st }}$ July have been shown in Table 6. Rice and wheat stocks accumulated to the extent of 63 million tonnes by July 2002 much above the optimal Minimum Buffer Norms of 24.3 million tonnes. This resulted from continuous rise in procurement prices, coupled with the rise in issue prices and the obligation to purchase all grains offered by the farmers.

TABLE 6: Buffer Stock of Food grains: Rice and Wheat (in million tonnes)

\begin{tabular}{|c|c|c|}
\hline Year & $\mathbf{1}^{\text {st }}$ July Actual Buffer Stock & $\mathbf{1}^{\text {st }}$ July Norm of Buffer Stock \\
\hline 2002 & 63.0 & 24.3 \\
\hline 2003 & 35.2 & 24.3 \\
\hline 2004 & 29.9 & 24.3 \\
\hline 2005 & 24.5 & 26.9 \\
\hline 2006 & 19.4 & 26.9 \\
\hline 2007 & 23.9 & 26.9 \\
\hline 2008 & 36.2 & 29.9 \\
\hline 2009 & 52.5 & 31.9 \\
\hline 2010 & 57.8 & 31.9 \\
\hline & 64.0 & 31.9 \\
\hline
\end{tabular}

Source: Economic Survey, GOI, Various Issues [12]

A major cause of reduction in the food stocks in 2003 was drought. In fact, the actual buffer stocks in 2005, 2006 and 2007 were below the norm and the country had to import wheat during 2006-08. However, the stocks accumulated thereafter and in 2008 and 2009 were once again much higher than the norm. In 2011, the government has more than 60 million tonnes of food grains. It is considered much in excess of the norm.

\subsection{Food Accessibility}

\section{Performance In Access To Food And Nutrition}

Ability of individuals to have access to available food stocks is another important aspect of food and nutrition security. To ensure access to food for all, the mere availability of food in the country is obviously not sufficient. The economic access of a household to adequate food depends on its purchasing power which includes the implicit value of its own production if any. In order to measure access to food in India, one of the key indicators used by many scholars and commentators is that of food grain consumption. Large-scale sample surveys carried out by the National Sample Survey Organization (NSSO) provide data on physical quantities of cereals, pulses and other key items of food consumed by a household over a definite time period at regular intervals of time.

Table-7 presents the Trend in per capita direct consumption of cereals and pulses as food, $\mathrm{kg} / \mathrm{year}$ since 1973-74. The NSSO data reveal that the per capita consumption of cereals has been declining since the early 1970s. The percentage changes in per capita consumption of cereals, pulses and food grains have been shown in Table-8. As shown in Table-7, the per capita yearly consumption of cereals has been continuously declining since 1973-74 both in rural and urban areas.

TABLE- 7: Trend in per capita direct consumption of cereals and pulses as food, $\mathrm{kg} / \mathrm{year}$

\begin{tabular}{|c|c|c|c|c|c|c|c|}
\hline & Commodity & 1973-74 & 1983 & 1993-94 & $2004-05$ & 2011-12\# & 2020-21\# \\
\hline \multirow[t]{7}{*}{ A. } & \multicolumn{7}{|l|}{ Rural } \\
\hline & Rice & 83.95 & 80.67 & 85.41 & 79.68 & 76.70 & 73.37 \\
\hline & Wheat & 42.83 & 54.26 & 53.53 & 52.23 & 51.18 & 49.81 \\
\hline & Coarse cereals & 56.82 & 45.14 & 24.09 & 15.52 & 12.15 & 9.50 \\
\hline & Total cereals & 183.60 & 180.07 & 163.03 & 147.44 & 140.04 & 132.68 \\
\hline & Pulses & & & 9.25 & 8.58 & 8.41 & 8.36 \\
\hline & Foodgrain & & & 172.28 & 156.01 & 148.45 & 141.04 \\
\hline \multirow[t]{5}{*}{ B. } & \multicolumn{7}{|l|}{ Urban } \\
\hline & Rice & 65.46 & 64.73 & 64.36 & 59.04 & 56.21 & 53.04 \\
\hline & Wheat & 52.56 & 58.64 & 57.43 & 56.53 & 54.71 & 52.34 \\
\hline & Coarse cereals & 19.71 & 14.11 & 7.55 & 5.39 & 4.35 & 3.49 \\
\hline & Total cereals & 137.73 & 137.48 & 129.33 & 120.96 & 115.27 & 108.87 \\
\hline
\end{tabular}


Food Security in India: Performance and Concerns

\begin{tabular}{|c|c|c|c|c|c|c|c|}
\hline & Pulses & & & 10.46 & 10.03 & 10.40 & 11.50 \\
\hline & Foodgrain & & & 139.80 & 130.99 & 125.68 & 120.37 \\
\hline \multirow[t]{7}{*}{ C. } & \multicolumn{7}{|l|}{ Rural +Urban } \\
\hline & \begin{tabular}{|l|} 
Rice \\
\end{tabular} & 79.98 & 76.87 & 79.92 & 73.77 & 70.53 & 66.83 \\
\hline & Wheat & 44.91 & 55.30 & 54.55 & 53.46 & 52.24 & 50.62 \\
\hline & Coarse cereals & 48.86 & 37.76 & 19.77 & 12.62 & 9.80 & 7.57 \\
\hline & Total cereals & 173.76 & 169.94 & 154.24 & 139.86 & 132.58 & 125.01 \\
\hline & Pulses & & & 9.56 & 8.99 & 9.01 & 9.37 \\
\hline & Foodgrain & & & 163.80 & 148.85 & 141.59 & 134.39 \\
\hline
\end{tabular}

\# Projections

Rice also includes rice products like chira, khoi, lawa, muri, rice powder etc. Wheat also includes maida, suji, rawa, sewai, noodle, bread

Source: Ramesh Chand (2009),'Demand for Food grains During $11^{\text {th }}$ Plan and towards 2020' [14].

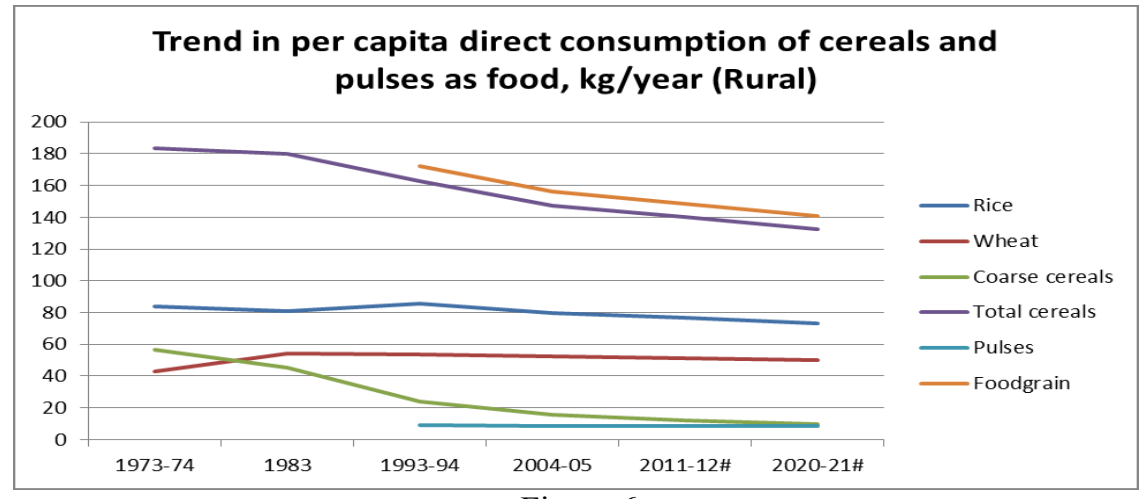

Source: Author's Compilation

Figure 6

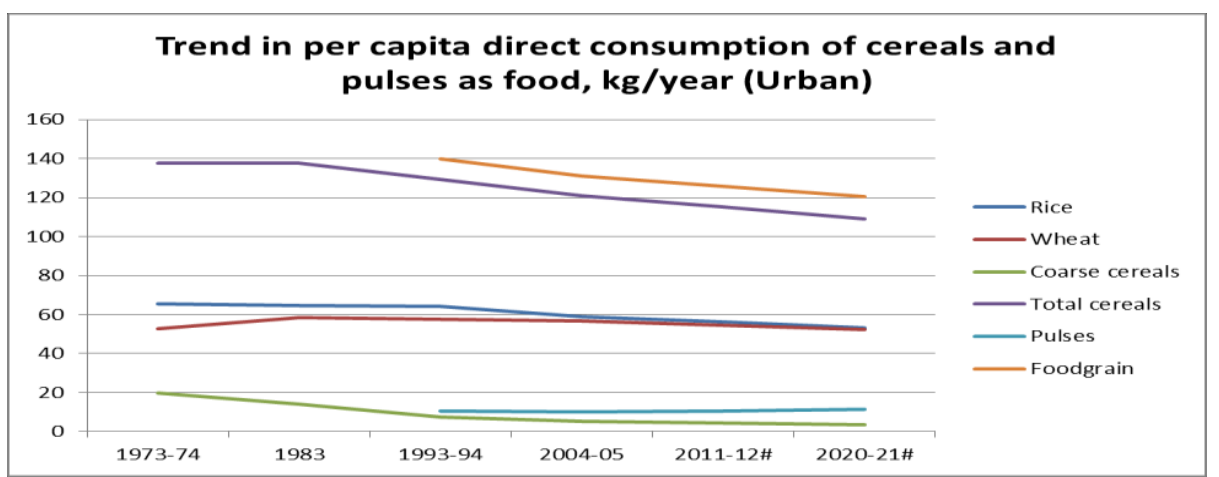

Source: Author's Compilation

Figure 7

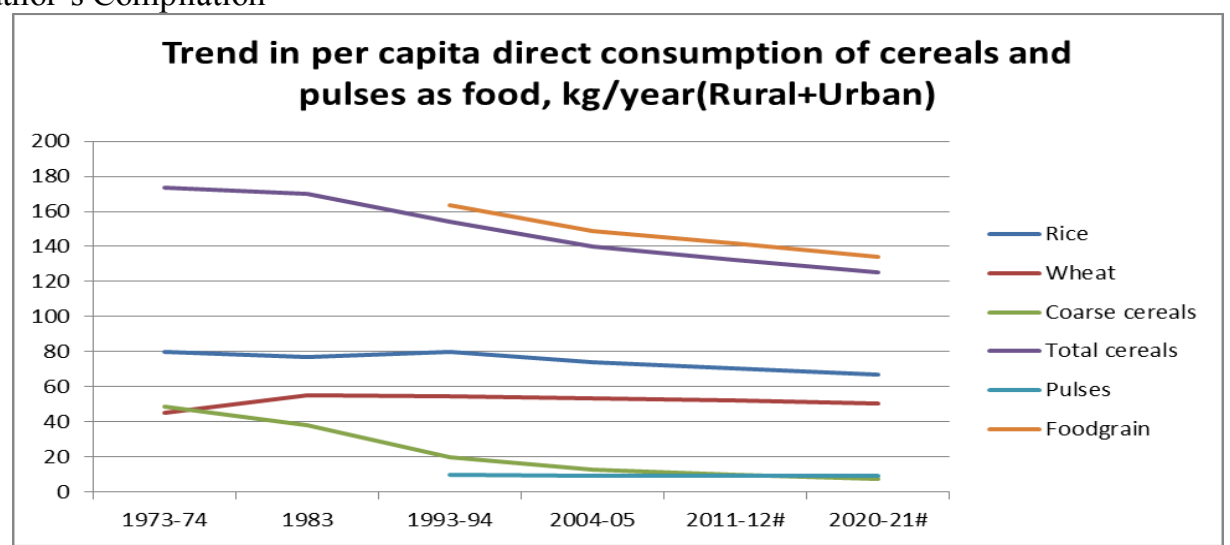

Source: Author's Compilation

Figure 8 
TABLE-8: Percentage Change in Per Capita Consumption of Total cereals, pulses and total food grains

\begin{tabular}{|l|c|c|c|c|c|c|}
\hline \multirow{2}{*}{ Commodity } & \multicolumn{2}{|c|}{ Rural } & \multicolumn{2}{c|}{ Urban } & \multicolumn{2}{c|}{ Rural +Urban } \\
\cline { 2 - 7 } & $\begin{array}{c}1993-94 \text { to } \\
2004-05\end{array}$ & $\begin{array}{c}2004-05 \text { to } \\
2011-12\end{array}$ & $\begin{array}{c}1993-94 \text { to } \\
2004-05\end{array}$ & $\begin{array}{c}2004-05 \text { to } \\
2011-12\end{array}$ & $\begin{array}{c}1993-94 \text { to } \\
2004-05\end{array}$ & $\begin{array}{c}2004-05 \text { to } \\
2011-12\end{array}$ \\
\hline Total cereals & -9.56 & -5.02 & -6.47 & -4.70 & -9.32 & -5.21 \\
\hline Pulses & -7.24 & -1.98 & -4.11 & 3.69 & -5.96 & 0.22 \\
\hline Food grain & -9.44 & -4.85 & -6.30 & -4.05 & -9.13 & -4.88 \\
\hline
\end{tabular}

Source: Calculated by Author from Table- 7

At all India level, per capital consumption of cereals declined from $154.24 \mathrm{~kg}$ per person per year during 1973-74 to $139.86 \mathrm{~kg}$ during 2004-05(by 19.5 percent). Per capita consumption of foodgrains also declined from $163.80 \mathrm{~kg}$ per person per year during 1993-94 to $148.85 \mathrm{~kg}$ during 2004-05(by 9.13percent). Per capita yearly consumption of cereals and foodgrains are projected to decline further in 2011-12 and2020-21.

Some argue that declining demand for cereals is due to dietary diversification that is diversion of demand towards livestock products and fruits and vegetables.Despite this shift in dietary pattern, food grains are considered to be of paramount importance for household food and nutrition security. Because, first, cereal and pulses are staple foods and there is no perfect substitution between staple foods and other foods. Secondly, compared to other foods, food grains are the major and the cheapest source of energy and protein and are vital for food and nutrition security of low income masses. Lastly, as a result of rising per capita income, production and consumption of livestock products has increased. This requires high growth in use of grain as feed for livestock. Because of these reasons, food grains continue to be the main pillars of food security in the country and any slackness in their production can result into persistent price shock and adverse impact on common people [14]. An alternative view is that decline in demand for food grain is due to loss of purchasing power by the poor largely due to deteriorating livelihood security. This view is consistent with the view that declining demand for food grain is due to rising food grain prices as a consequence to the adoption of Structural Adjustment Policies (SAPs) involving deflationary macroeconomic policies and the opening up of the agricultural sector.

\subsection{Performance on Nutrition Indicators}

The per capita calorie intake declined from $2139 \mathrm{kcal}$ per day in 1991-92 to $1834 \mathrm{kcal}$ per day in 200506 (Table 9). During the same period, percapita protein consumption declined from 54.1grams to 49.4 grams per day.

TABLE-9: Per capita Average Daily Intake of Proteins and Calories in India

\begin{tabular}{|c|c|c|}
\hline Year & Proteins (Grams) & Calories (KiloCalories) \\
\hline $1991-92$ & 54.1 & 2139 \\
\hline $1993-94$ & 55.8 & 2187 \\
\hline $1994-95$ & 55.8 & 2172 \\
\hline $1996-97$ & 54.0 & 2114 \\
\hline 2001 & 50.7 & 1955 \\
\hline $2004-05$ & 57.0 & 2033 \\
\hline $2005-06$ & 49.4 & 1834 \\
\hline
\end{tabular}

Source: Selected Socio-Economic Statistics India, Government of India 2011[15].

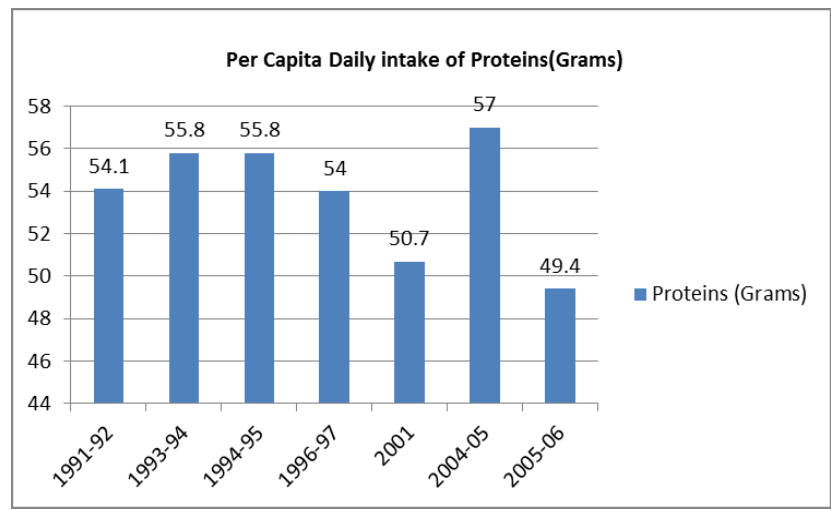

Figure 9

Source: Author's Compilation 


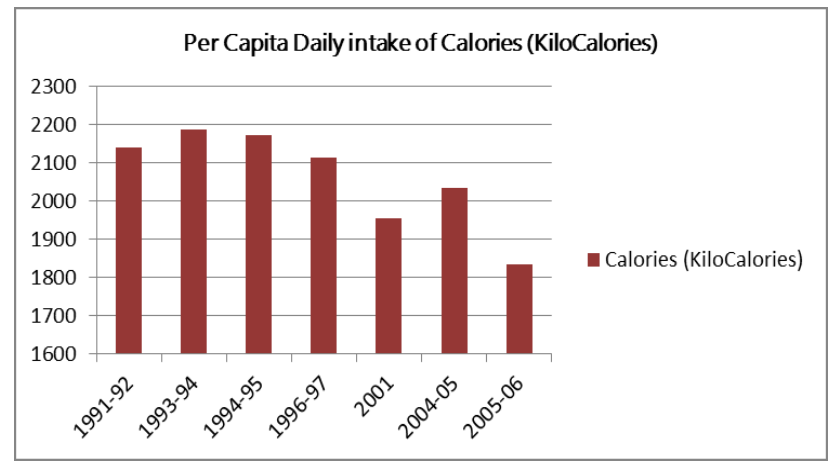

Figure 10

Source: Author's Compilation

\subsection{Right to Food and National Food Security Act}

The Presidential address to Parliament in 2009 indicated that implementation of the National Food Security Act would provide a statutory basis for a framework assuring food security for all. According to this law, every family below the poverty line in rural and urban areas will be entitled to 25 kilograms of rice or wheat per month at Rs. 3 per kilogram. The statutory guarantee to food with fixed entitlements to the poor is considered as an important step in the direction of ensuring food and nutritional security of the country. Although the ongoing 'targeted public distribution system' (TPDS) is supposed to provide subsidized food grains to the BPL population, the legislative measure may lead to better accountability since it would make the PDS system more responsive in reaching out to the targeted population. Since the announcement of the proposed food security law, several people have raised a number of policylevel and operational issues that need to be addressed while extending food guarantee to the citizens through a statutory mandate. There has been a serious debate on the question: should thePDS be targeted or universal? The advantage of universal PDS is that targeting errors can be minimized, particularly the exclusion error (exclusion of poor). Also, a right generally implies applicability to the entire population of the nation. The Right to Food campaign demands a comprehensive 'Food Entitlements Act' that goes beyond the narrow promise of supplying food grains to BPL population [2].

\section{Conclusion}

In this paper an attempt has been made to examine the performance in food security in terms of availability, access, and absorption or nutrition. It may be noted that all three are inter-related. For example, availability and access to food can increase nutrition among the households. India is more or less self sufficient in cereals but deficient in pulses. The food grains production has deteriorated when India entered in the era of globalization. The free market play has adversely affected the production of food grains and the rate of growth of food grains production declined after the introduction of New Economic Policy (NEP) in India. In the period just after green revolution (1967-68 to 1979-80) and during the period of matured green revolution (1980-81 to $89-90)$ the food grain production increased at an annual rate of 2.78 percent and 4.62 percent respectively whereas in early economic reforms (1990-91 to 1999-00), and economic reforms (2000-01 to 2011-12 period the food grain production increased at an annual rate of 2.43 percent and 1.52 percent respectively. So far as the accessibility aspect of food security is concerned, long term trend in consumption pattern at household level shows that per capita direct consumption of food grains has been declining. One reason quite often cited to justify this fall is diversification of demand. But as per findings of a research study [14], despite dietary diversification, involving sharp decline in per capita direct consumption of food grains, the total demand for cereals and pulses is projected to grow at about 2 percent per year because of increase in population and increase in indirect demand. This growth rate is far greater than the growth rate experienced in domestic production of food grains during the last decade. This has created serious imbalances between domestic production and demand. For some time it was met by liquidating stock and cutting down on export. If domestic production of food grain fails to grow at the required rate, it would lead to a decline in export of rice and ultimately to increased dependence on import of wheat and rice and pulses to meet the domestic demand for food grains. Further India's performance in food security on nutritional outcomes has not been very satisfactory. The Global Food Security Index 2012, released in New Delhi in September, 2012, placed India in a "moderate" category. It ranked India 66th among 105 nations and cited affordability rather than availability as a key food security threat for Indians.Countries were assessed to gauge those most and least vulnerable to food insecurity through the categories of affordability, availability, and quality and safety[16].

India scored highest in food availability (51.3) but lowest (38.4) in terms of food access. It also points to its poor ability to move food efficiently because of infrastructure problems, despite being the world's largest 
producer of milk and edible oils, and the second-largest producer of wheat and sugar [16]. Similarly, in food security index 2013, India slipped to $70^{\text {th }}$ position [17]. According to Food and trade policy analyst Devinder Sharma, we live in paradoxical times, and it was not the shortage of food but the lack of a proper food distribution network that was to blame. He further states that of India's 1.2 billion, an estimated 320 million people go to bed hungry. But this too is not for the want of food, in view of the fact that India produced a surplus of 82.3 million tonnes of crops as of June 2012. Bulk of this however lies rotting in warehouses run by the Food Corporation of India [18].

\section{Scope for Future Research:}

(i) Further studies need to be carried out making comparative analysis of states' performance on agricultural front (specifically focusing on the states where agriculture contributes comparatively larger share to state domestic product) and working/implementation of the PDS.

(ii) Studies may be conducted to Search the causes for varying state performance and to analyse the specific strategic policies adopted by successful states and also to analyse the feasibility of and constraints in applying the similar policies in other states.

\section{References}

[1] NRAA (2011). Challenges of Food Security and its Management 2011, National Rainfed Area Authority, Planning Commission, Government of India.

[2] S. Mahendra Dev and Alakh N. Sharma (2010): "Food Security in India: Performance, Challenges and Policies", Oxfam India working papers series, September, Retrieved 25November,2012 $<$ www.oxfamindia.org/.../VII.\%20Food\%20Security\%20in\%20India-Perf.. >.

[3] M.S. Swaminathan Research Foundation (2008): "Report on the state of Food Insecurity in Rural India", Centre for Research on Sustainable Agriculture and Rural Development, Retrieved15th November, 2012 from < www.mssrf.org/.../>.

[4] World Health Organisation (2012): "Food Security", Retrieved 11 october, 2012 from www.who.int/trade/glossary/story028/en.

[5] Government of India (2008): "Draft 11th Five Year Plan", Planning Commission, Government of India

[6] Planning Commission: “Agriculture Strategy for Eleventh Plan", Government of India, Retrieved 25 October, 2012 from $<$ planningcommission .nic.in/aboutus/speech/.../ AgricultureStrategy .doc $>$.

[7] Planning Commission (2011). "Faster, Sustainable and More Inclusive Growth- An Approach to the Twelfth Five Year Plan \{201217)" Government of India, October.

[8] Government of India (2007a), "Report of Steering Committee on Agriculture for the XIth Plan", Planning Commission, Government of India

[9] Department of Agriculture and Cooperation (2011): "Agricultural Statistics at a Glance" Ministry of Agriculture, Government of India.

[10] Central Bureau of Health Intelligence, India (2010): "Socio-Economic Indicators", Retrieved January 5,2014 from www.cbhidghs.nic.in/

[11] Department of Agriculture and Cooperation (2013).Pocket Book on Agricultural Statistics, DAC, Min of Agriculture, GOI, Retrieved January 5,2014 from www.scribd.com/doc/220204847/ AgricultralStats-Inside-website-Book

[12] Government of India, "Economic Survey", Various Issues.

[13] Government of India. Annual Report 2010-11. Department of Food and Public Distribution, Ministry of Consumer Affairs.

[14] Ramesh Chand (2009),'Demand for Foodgrains During 11th Plan and Towards 2020', Policy Brief, National Centre for Agricultural Economics and Policy Research, New Delhi, Retrieved 20th November 2012.from <www.ncap.res.in/upload_files/ policy brief/pb28.pdf>.

[15] Government of India (2011): "Selected Socio-Economic Statistics, India 2011", Central Statistics Office, New Delhi.

[16] Zia Haq (2012): "How affordable is food in India?, Hindustan Times,September,26, Retrieved 20th December 2012 from $<$ www.hindustantimes.com/.../How-affordable-is-food-gin-India/Article1-9>.

[17] The Economist Intelligence Unit (2013). Global food security index 2013. Retrieved February 5, 2014 from foodsecurityindex.eiu.com/.../DownloadResource?...EIU\%20Global\%20.

[18] Madhavi Rajadhyaksha (2012): "Food distribution, not shortage to blame for India's food insecurity", Times of India, Mumbai, December 21, Retrieved 23th December 2012 from < articles.timesofindia. indiatimes.com > Collections> 


\section{APPENDIX}

Table-A1 Food Grain Production in India (1950-51 to 2011-12)

\begin{tabular}{|c|c|c|c|c|c|c|}
\hline \multirow[t]{2}{*}{ Year } & \multicolumn{2}{|c|}{$\begin{array}{c}\text { Cereals } \\
\end{array}$} & \multicolumn{2}{|c|}{$\begin{array}{c}\text { Pulses } \\
\end{array}$} & \multicolumn{2}{|c|}{ Total Food grains } \\
\hline & Production & $\begin{array}{l}\text { Percentage } \\
\text { Change* }\end{array}$ & Production & $\begin{array}{l}\text { Percentage } \\
\text { Change* }\end{array}$ & Production & $\begin{array}{l}\text { Percentage } \\
\text { Change* }\end{array}$ \\
\hline $1950-51$ & 42.42 & - & 8.41 & - & 50.83 & - \\
\hline $1952-53$ & 50.01 & 14.78 & 9.19 & 9.14 & 59.2 & 13.87 \\
\hline $1953-54$ & 59.2 & 18.38 & 10.62 & 15.56 & 69.82 & 17.94 \\
\hline $1954-55$ & 57.08 & -3.58 & 10.95 & 3.11 & 68.03 & -2.56 \\
\hline $1956-57$ & 58.31 & 4.48 & 11.55 & 4.62 & 69.86 & 4.50 \\
\hline $1957-58$ & 54.75 & -6.11 & 9.56 & -17.23 & 64.31 & -7.94 \\
\hline $1958-59$ & 63.99 & 16.88 & 13.15 & 37.55 & 77.14 & 19.95 \\
\hline $1959-60$ & 64.87 & 1.38 & 11.8 & -10.27 & 76.67 & -0.61 \\
\hline 1960-61 & 69.32 & 6.86 & 12.7 & 7.63 & 82.02 & 6.98 \\
\hline 1961-62 & 70.95 & 2.35 & 11.76 & -7.40 & 82.71 & 0.84 \\
\hline $1965-66$ & 62.41 & -18.88 & 9.94 & -19.97 & 72.35 & -19.04 \\
\hline 1966-67 & 65.88 & 5.56 & 8.35 & -16.00 & 74.23 & 2.60 \\
\hline $1967-68$ & 82.95 & 25.91 & 12.1 & 44.91 & 95.05 & 28.05 \\
\hline 1968-69 & 83.59 & 0.77 & 10.42 & -13.88 & 94.01 & -1.09 \\
\hline $1969-70$ & 87.81 & 5.05 & 11.69 & 12.19 & 99.5 & 5.84 \\
\hline $1970-71$ & 96.6 & 10.01 & 11.82 & 1.11 & 108.42 & 8.96 \\
\hline $1971-72$ & 94.08 & -2.61 & 11.09 & -6.18 & 105.17 & -3.00 \\
\hline $1972-73$ & 87.12 & -7.40 & 9.91 & -10.64 & 97.03 & -7.74 \\
\hline 1973-74 & 94.66 & 8.65 & 10.01 & 1.01 & 104.67 & 7.87 \\
\hline $1974-75$ & 89.81 & -5.12 & 10.02 & 0.10 & 99.83 & -4.62 \\
\hline $1975-76$ & 107.99 & 20.24 & 13.04 & 30.14 & 121.03 & 21.24 \\
\hline $1983-84$ & 139.48 & 18.54 & 12.89 & 8.68 & 152.37 & 17.64 \\
\hline $1984-85$ & 133.58 & -4.23 & 11.96 & -7.21 & 145.54 & -4.48 \\
\hline $1985-86$ & 137.08 & 2.62 & 13.36 & 11.71 & 150.44 & 3.37 \\
\hline $1986-87$ & 131.71 & -3.92 & 11.71 & -12.35 & 143.42 & -4.67 \\
\hline $1987-88$ & 129.39 & -1.76 & 10.96 & -6.40 & 140.35 & -2.14 \\
\hline 1988-89 & 156.07 & 20.62 & 13.85 & 26.37 & 169.92 & 21.07 \\
\hline $1989-90$ & 158.18 & 1.35 & 12.86 & -7.15 & 171.04 & 0.66 \\
\hline $1990-91$ & 162.13 & 2.50 & 14.26 & 10.89 & 176.39 & 3.13 \\
\hline 1991-92 & 156.36 & -3.56 & 12.02 & -15.71 & 168.38 & -4.54 \\
\hline 1992-93 & 166.66 & 6.59 & 12.82 & 6.66 & 179.48 & 6.59 \\
\hline 1993-94 & 170.96 & 2.58 & 13.3 & 3.74 & 184.26 & 2.66 \\
\hline 1994-95 & 177.46 & 3.80 & 14.04 & 5.56 & 191.5 & 3.93 \\
\hline $1995-96$ & 168.11 & -5.27 & 12.31 & -12.32 & 180.42 & -5.79 \\
\hline 1996-97 & 185.19 & 10.16 & 14.24 & 15.68 & 199.43 & 10.54 \\
\hline $1997-98$ & 179.29 & -3.19 & 13.83 & -2.88 & 193.12 & -3.16 \\
\hline 1998-99 & 188.7 & 5.25 & 14.91 & 7.81 & 203.61 & 5.43 \\
\hline 1999-00 & 196.39 & 4.08 & 13.41 & -10.06 & 209.8 & 3.04 \\
\hline $2000-01$ & 185.74 & -5.42 & 11.07 & -17.45 & 196.81 & -6.19 \\
\hline 2001-02 & 199.48 & 7.40 & 13.37 & 20.78 & 212.85 & 8.15 \\
\hline $2002-03$ & 163.65 & -17.96 & 11.13 & -16.75 & 174.78 & -17.89 \\
\hline 2003-04 & 198.28 & 21.16 & 14.91 & 33.96 & 213.19 & 21.98 \\
\hline $2004-05$ & 185.23 & -6.58 & 13.13 & -11.94 & 198.36 & -6.96 \\
\hline
\end{tabular}

Source: DBIE, Reserve Bank of India 
Food Security in India: Performance and Concerns

*Calculated by Author

Table-A2 Area under Food Grain Production in India (1950-51 to 2011-12)

\begin{tabular}{|c|c|c|c|c|c|c|}
\hline \multirow{2}{*}{ Year } & \multicolumn{2}{|c|}{ Cereals } & \multicolumn{2}{|c|}{ Pulses } & \multicolumn{2}{|c|}{ Total Food grains } \\
\hline & Area & $\begin{array}{c}\text { Percentage } \\
\text { Change* }\end{array}$ & Area & $\begin{array}{c}\text { Percentage } \\
\text { Change* }\end{array}$ & Area & $\begin{array}{l}\text { Percentage } \\
\text { Change* }\end{array}$ \\
\hline $1950-51$ & 78.23 & - & 19.09 & - & 97.32 & - \\
\hline $1951-52$ & 78.18 & -0.06 & 18.78 & -1.62 & 96.96 & -0.37 \\
\hline $1952-53$ & 82.25 & 5.21 & 19.84 & 5.64 & 102.09 & 5.29 \\
\hline $1953-54$ & 87.34 & 6.19 & 21.73 & 9.53 & 109.07 & 6.84 \\
\hline 1954-55 & 85.95 & -1.59 & 21.91 & 0.83 & 107.86 & -1.11 \\
\hline $1955-56$ & 87.34 & 1.62 & 23.22 & 5.98 & 110.56 & 2.50 \\
\hline $1956-57$ & 87.82 & 0.55 & 23.32 & 0.43 & 111.14 & 0.52 \\
\hline $1957-58$ & 86.94 & -1.00 & 22.54 & -3.34 & 109.48 & -1.49 \\
\hline 1958-59 & 90.45 & 4.04 & 24.31 & 7.85 & 114.76 & 4.82 \\
\hline $1959-60$ & 90.99 & 0.60 & 24.83 & 2.14 & 115.82 & 0.92 \\
\hline 1960-61 & 92.02 & 1.13 & 23.56 & -5.11 & 115.58 & -0.21 \\
\hline $1961-62$ & 92.99 & 1.05 & 24.24 & 2.89 & 117.23 & 1.43 \\
\hline $1962-63$ & 93.57 & 0.62 & 24.27 & 0.12 & 117.84 & 0.52 \\
\hline 1963-64 & 93.24 & -0.35 & 24.18 & -0.37 & 117.42 & -0.36 \\
\hline 1964-65 & 94.23 & 1.06 & 23.88 & -1.24 & 118.11 & 0.59 \\
\hline $1965-66$ & 92.38 & -1.96 & 22.72 & -4.86 & 115.1 & -2.55 \\
\hline 1966-67 & 93.18 & 0.87 & 22.12 & -2.64 & 115.3 & 0.17 \\
\hline $1967-68$ & 98.77 & 6.00 & 22.65 & 2.40 & 121.42 & 5.31 \\
\hline 1968-69 & 99.17 & 0.40 & 21.26 & -6.14 & 120.43 & -0.82 \\
\hline $1969-70$ & 101.55 & 2.40 & 22.02 & 3.57 & 123.57 & 2.61 \\
\hline $1970-71$ & 101.78 & 0.23 & 22.54 & 2.36 & 124.32 & 0.61 \\
\hline 1971-72 & 100.47 & -1.29 & 22.15 & -1.73 & 122.62 & -1.37 \\
\hline $1972-73$ & 98.36 & -2.10 & 20.92 & -5.55 & 119.28 & -2.72 \\
\hline 1973-74 & 103.11 & 4.83 & 23.43 & 12.00 & 126.54 & 6.09 \\
\hline $1974-75$ & 99.05 & -3.94 & 22.03 & -5.98 & 121.08 & -4.31 \\
\hline $1975-76$ & 103.73 & 4.72 & 24.45 & 10.99 & 128.18 & 5.86 \\
\hline 1976-77 & 101.37 & -2.28 & 22.98 & -6.01 & 124.35 & -2.99 \\
\hline $1977-78$ & 104.02 & 2.61 & 23.5 & 2.26 & 127.52 & 2.55 \\
\hline $1978-79$ & 105.35 & 1.28 & 23.66 & 0.68 & 129.01 & 1.17 \\
\hline $1979-80$ & 102.95 & -2.28 & 22.26 & -5.92 & 125.21 & -2.95 \\
\hline $1980-81$ & 104.21 & 1.22 & 22.46 & 0.90 & 126.67 & 1.17 \\
\hline 1981-82 & 105.3 & 1.05 & 23.84 & 6.14 & 129.14 & 1.95 \\
\hline $1982-83$ & 102.26 & -2.89 & 22.83 & -4.24 & 125.09 & -3.14 \\
\hline 1983-84 & 107.62 & 5.24 & 23.54 & 3.11 & 131.16 & 4.85 \\
\hline 1984-85 & 103.93 & -3.43 & 22.74 & -3.40 & 126.67 & -3.42 \\
\hline $1985-86$ & 103.61 & -0.31 & 24.42 & 7.39 & 128.03 & 1.07 \\
\hline 1986-87 & 104.04 & 0.42 & 23.16 & -5.16 & 127.2 & -0.65 \\
\hline $1987-88$ & 98.42 & -5.40 & 21.27 & -8.16 & 119.69 & -5.90 \\
\hline 1988-89 & 104.52 & 6.20 & 23.15 & 8.84 & 127.67 & 6.67 \\
\hline $1989-90$ & 103.36 & -1.11 & 23.41 & 1.12 & 126.77 & -0.70 \\
\hline 1990-91 & 103.18 & -0.17 & 24.66 & 5.34 & 127.84 & 0.84 \\
\hline 1991-92 & 99.33 & -3.73 & 22.54 & -8.60 & 121.87 & -4.67 \\
\hline $1992-93$ & 100.79 & 1.47 & 22.36 & -0.80 & 123.15 & 1.05 \\
\hline 1993-94 & 100.51 & -0.28 & 22.25 & -0.49 & 122.76 & -0.32 \\
\hline 1994-95 & 100.68 & 0.17 & 23.03 & 3.51 & 123.71 & 0.77 \\
\hline $1995-96$ & 98.73 & -1.94 & 22.28 & -3.26 & 121.01 & -2.18 \\
\hline $1996-97$ & 101.13 & 2.43 & 22.45 & 0.76 & 123.58 & 2.12 \\
\hline $1997-98$ & 100.98 & -0.15 & 22.87 & 1.87 & 123.85 & 0.22 \\
\hline 1998-99 & 101.66 & 0.67 & 23.5 & 2.75 & 125.16 & 1.06 \\
\hline 1999-00 & 101.99 & 0.32 & 21.12 & -10.13 & 123.11 & -1.64 \\
\hline $2000-01$ & 100.7 & -1.26 & 20.35 & -3.65 & 121.05 & -1.67 \\
\hline 2001-02 & 100.76 & 0.06 & 22.01 & 8.16 & 122.77 & 1.42 \\
\hline 2002-03 & 93.37 & -7.33 & 20.5 & -6.86 & 113.87 & -7.25 \\
\hline 2003-04 & 99.99 & 7.09 & 23.46 & 14.44 & 123.45 & 8.41 \\
\hline 2004-05 & 97.32 & -2.67 & 22.76 & -2.98 & 120.08 & -2.73 \\
\hline $2005-06$ & 99.18 & 1.91 & 22.39 & -1.63 & 121.57 & 1.24 \\
\hline 2006-07 & 100.51 & 1.34 & 23.19 & 3.57 & 123.7 & 1.75 \\
\hline $2007-08$ & 100.43 & -0.08 & 23.63 & 1.90 & 124.06 & 0.29 \\
\hline 2008-09 & 100.74 & 0.31 & 22.09 & -6.52 & 122.83 & -0.99 \\
\hline 2009-10 & 97.73 & -2.99 & 23.39 & 5.89 & 121.12 & -1.39 \\
\hline $2010-11$ & 99.45 & 1.76 & 26.28 & 12.36 & 125.73 & 3.81 \\
\hline $2011-12$ & 100.52 & 1.08 & 26.22 & -0.23 & 126.74 & 0.80 \\
\hline
\end{tabular}

Source: DBIE, Reserve Bank of India 
Food Security in India: Performance and Concerns

Table-A3 Yield of Food Grain Production in India (1950-51 to 2011-12)

(Kg./hectare)

\begin{tabular}{|c|c|c|c|c|c|c|}
\hline \multirow[t]{2}{*}{ Year } & \multicolumn{2}{|c|}{ Cereals } & \multicolumn{2}{|c|}{ Pulses } & \multicolumn{2}{|c|}{ Total Food grains } \\
\hline & Yield & $\begin{array}{l}\text { Percentage } \\
\text { Change* }\end{array}$ & Yield & $\begin{array}{l}\text { Percentage } \\
\text { Change* }\end{array}$ & Yield & $\begin{array}{l}\text { Percentage } \\
\text { Change* }\end{array}$ \\
\hline $1950-51$ & 542 & - & 441 & - & 522 & - \\
\hline $1951-52$ & 557 & 2.77 & 448 & 1.59 & 536 & 2.68 \\
\hline $1952-53$ & 608 & 9.16 & 463 & 3.35 & 580 & 8.21 \\
\hline $1953-54$ & 678 & 11.51 & 489 & 5.62 & 640 & 10.34 \\
\hline $1954-55$ & 664 & -2.06 & 500 & 2.25 & 631 & -1.41 \\
\hline $1955-56$ & 639 & -3.77 & 476 & -4.80 & 605 & -4.12 \\
\hline $1956-57$ & 664 & 3.91 & 495 & 3.99 & 629 & 3.97 \\
\hline $1957-58$ & 630 & -5.12 & 424 & -14.34 & 587 & -6.68 \\
\hline 1958-59 & 707 & 12.22 & 541 & 27.59 & 672 & 14.48 \\
\hline $1959-60$ & 713 & 0.85 & 475 & -12.20 & 662 & -1.49 \\
\hline $1960-61$ & 753 & 5.61 & 539 & 13.47 & 710 & 7.25 \\
\hline $1961-62$ & 763 & 1.33 & 485 & -10.02 & 706 & -0.56 \\
\hline $1962-63$ & 733 & -3.93 & 475 & -2.06 & 680 & -3.68 \\
\hline 1963-64 & 757 & 3.27 & 416 & -12.42 & 687 & 1.03 \\
\hline $1964-65$ & 817 & 7.93 & 520 & 25.00 & 757 & 10.19 \\
\hline $1965-66$ & 676 & -17.26 & 438 & -15.77 & 629 & -16.91 \\
\hline 1966-67 & 707 & 4.59 & 377 & -13.93 & 644 & 2.38 \\
\hline $1967-68$ & 840 & 18.81 & 534 & 41.64 & 783 & 21.58 \\
\hline 1968-69 & 843 & 0.36 & 490 & -8.24 & 781 & -0.26 \\
\hline $1969-70$ & 865 & 2.61 & 531 & 8.37 & 805 & 3.07 \\
\hline $1970-71$ & 949 & 9.71 & 524 & -1.32 & 872 & 8.32 \\
\hline $1971-72$ & 936 & -1.37 & 501 & -4.39 & 858 & -1.61 \\
\hline $1972-73$ & 886 & -5.34 & 474 & -5.39 & 813 & -5.24 \\
\hline 1973-74 & 918 & 3.61 & 427 & -9.92 & 827 & 1.72 \\
\hline 1974-75 & 907 & -1.20 & 455 & 6.56 & 824 & -0.36 \\
\hline $1975-76$ & 1,041 & 14.77 & 533 & 17.14 & 944 & 14.56 \\
\hline $1976-77$ & 985 & -5.38 & 494 & -7.32 & 894 & -5.30 \\
\hline $1977-78$ & 1,100 & 11.68 & 510 & 3.24 & 991 & 10.85 \\
\hline $1978-79$ & 1,136 & 3.27 & 515 & 0.98 & 1,022 & 3.13 \\
\hline $1979-80$ & 982 & -13.56 & 385 & -25.24 & 876 & -14.29 \\
\hline $1980-81$ & 1,142 & 16.29 & 473 & 22.86 & 1,023 & 16.78 \\
\hline 1981-82 & 1,157 & 1.31 & 483 & 2.11 & 1,032 & 0.88 \\
\hline $1982-83$ & 1,151 & -0.52 & 519 & 7.45 & 1,035 & 0.29 \\
\hline $1983-84$ & 1,296 & 12.60 & 548 & 5.59 & 1,162 & 12.27 \\
\hline 1984-85 & 1,285 & -0.85 & 526 & -4.01 & 1,149 & -1.12 \\
\hline $1985-86$ & 1,323 & 2.96 & 547 & 3.99 & 1,175 & 2.26 \\
\hline $1986-87$ & 1,266 & -4.31 & 506 & -7.50 & 1,128 & -4.00 \\
\hline $1987-88$ & 1,315 & 3.87 & 515 & 1.78 & 1,173 & 3.99 \\
\hline $1988-89$ & 1,493 & 13.54 & 598 & 16.12 & 1,331 & 13.47 \\
\hline $1989-90$ & 1,530 & 2.48 & 549 & -8.19 & 1,349 & 1.35 \\
\hline 1990-91 & 1,571 & 2.68 & 578 & 5.28 & 1,380 & 2.30 \\
\hline 1991-92 & 1,574 & 0.19 & 533 & -7.79 & 1,382 & 0.14 \\
\hline $1992-93$ & 1,654 & 5.08 & 573 & 7.50 & 1,457 & 5.43 \\
\hline 1993-94 & 1,701 & 2.84 & 598 & 4.36 & 1,501 & 3.02 \\
\hline 1994-95 & 1,763 & 3.64 & 610 & 2.01 & 1,546 & 3.00 \\
\hline $1995-96$ & 1,703 & -3.40 & 552 & -9.51 & 1,491 & -3.56 \\
\hline $1996-97$ & 1,831 & 7.52 & 635 & 15.04 & 1,614 & 8.25 \\
\hline $1997-98$ & 1,775 & -3.06 & 567 & -10.71 & 1,552 & -3.84 \\
\hline 1998-99 & 1,856 & 4.56 & 634 & 11.82 & 1,627 & 4.83 \\
\hline 1999-00 & 1,925 & 3.72 & 635 & 0.16 & 1,704 & 4.73 \\
\hline $2000-01$ & 1,844 & -4.21 & 544 & -14.33 & 1,626 & -4.58 \\
\hline 2001-02 & 1,980 & 7.38 & 607 & 11.58 & 1,734 & 6.64 \\
\hline $2002-03$ & 1,753 & -11.46 & 543 & -10.54 & 1,535 & -11.48 \\
\hline 2003-04 & 1,983 & 13.12 & 635 & 16.94 & 1,727 & 12.51 \\
\hline 2004-05 & 1,903 & -4.03 & 577 & -9.13 & 1,652 & -4.34 \\
\hline $2005-06$ & 1,968 & 3.42 & 598 & 3.64 & 1,715 & 3.81 \\
\hline $2006-07$ & 2,020 & 2.64 & 612 & 2.34 & 1,756 & 2.39 \\
\hline $2007-08$ & 2,151 & 6.49 & 625 & 2.12 & 1,860 & 5.92 \\
\hline 2008-09 & 2,183 & 1.49 & 659 & 5.44 & 1,909 & 2.63 \\
\hline $2009-10$ & 2,082 & -4.63 & 630 & -4.40 & 1,798 & -5.81 \\
\hline $2010-11$ & 2,247 & 7.93 & 689 & 9.37 & 1,921 & 6.84 \\
\hline 2011-12 & 2,390 & 6.36 & 649 & -5.81 & 1,993 & 3.75 \\
\hline
\end{tabular}

Source: DBIE, Reserve Bank of India

*Calculated by Author 